\title{
PENINGKATAN HASIL BELAJAR SISWA PADA MATA PELAJARAN PPKn DENGAN PEMBELAJARAN DIRECT INSTRUCTION BERBANTUKAN GOOGLE CLASSROOM
}

\author{
I Gusti Ngurah Adhi Windu \\ SMAN 2 Negara, Jembrana, Bali \\ email: ngrwind@yahoo.co.id
}

\begin{abstract}
Civics is a compulsory subject especially for senior high school students. Therefore, the students must have complete learning in each of the existing basic competencies. This study aims to improve students' learning outcomes in civics subject that implements direct instruction using google classroom. This study is Classroom Action Research with 34 students as the research subjects. The research instruments are test questions, interview guidelines, and observation guidelines. The data is collected using tests, observations, and interviews. The data is validated using triangulation techniques of theory and data. The technique of analysis data uses descriptive comparative technique. The result of study shows that there is an improvement of students' learning outcomes starting from pre-action activity to cycle II. It can be viewed from the percentages of classical completeness and success. This study concludes that students' learning outcomes in each cycle have improved and $75 \%$ of students have obtained scores above 70 (minimum completeness criteria of civics).
\end{abstract}

Keywords: direct instruction, google classroom, learning outcomes, Civics subject

\begin{abstract}
Abstrak: Mata pelajaran Pendidikan Pancasila dan Kewarganegaaan menjadi matapelajaran wajib di jenjang sekolah, khususnya di sekolah menengah atas. Untuk itu, siswa harus memiliki ketuntasan belajar pada setiap kompetensi dasar yang ada. Tujuan penelitian ini adalah untuk meningkatkan hasil belajar siswa pada mata pelajaran PPkn dengan penerapan model pembelajaran direct instruction berbantukan google classroom. Penelitian ini merupakan Penelitian Tindakan Kelas dengan subjek sebanyak 34 siswa. Instrumen penelitian menggunakan soal tes, pedoman wawancara, dan pedoman observasi. Teknik pengumpulan data menggunakan metode tes, observasi, dan wawancara. Data penelitian ini divalidasi dengan teknik triangulasi teori dan data. Teknik analisis data menggunakan teknik deksriptif komparatif. Hasil penelitian menunjukkan terdapat peningkatan hasil belajar siswa mulai dari kegiatan pratindakan sampai siklus II. Peningkatan hasil belajar tersebut dapat dilihat dari persentase ketuntasan klasikal dan persentase keberhasilan. Simpulan penelitian ini adalah hasil belajar siswa pada setiap siklus mengalami peningkatan dan sebanyak $75 \%$ siswa sudah mendapat nilai di atas 70 (KKM mata pelarajan PPKn).
\end{abstract}

Kata Kunci: direct instruction, google classroom, hasil belajar, mata pelajaran PPKn.

\section{PENDAHULUAN}

Matapelajaran Pendidikan Pancasila dan Kewarganegaaan menjadi matapelajaran wajib di jenjang sekolah, khususnya di sekolah menengah atas. Hal ini diperkuat bahwa pendidikan kewarganegaraan (PKn) merupakan matapelajaran wajib dalam kurikulum yang harus dimuat pada setiap jenis, jalur, dan jenjang pendidikan (UU no. 20 pasal 37 ayat 1) dengan tujuan dapat mengembangkan potensi individu warga negara Indonesia (Depdiknas, 2005) dan membangun partisipasi bermutu serta bertanggungjawab (Winataputra \& Budiansyah 2012) sehingga menjadi 
leading sector dalam pengembangan karakter siswa (Dianti, 2014), toleransi, solidaritas, dan keberanian kewarganegaraan (Birzea, 2000).

Kompetensi pembelajaran PPKn mencakup kompetensi sikap, pengetahuan, dan keterampilan (Lubis \& Sodeli, 2018). Ketiga komponen ini dapat mengembangkan kemampuan berpikir kritis, reflektif, analisis, tanggung jawab peserta didik (Rismayani, dkk., 2013), serta memiliki komitmen konstitusional (Tolib \& Nuryadi, 2017).

Penilaian sikap menjadi suatu yang penting sebagai bentuk implementasi pendidikan karakter (Rattu, 2017). Penilaian sikap mencakup adanya partisipasi, observasi, tes tertulis, unjuk kerja, angket, dan tes lisan (Permendikbud no. 49 tahun 2014).

Kompetensi pengetahuan merupakan alat ukur untuk mengetahui ingatan/hafalan, pemahaman, penerapan, analisis, sintesis, dan evaluasi peserta didik (Kunandar, 2013) serta mampu mengukur enam aspek pengetahuan siswa yang didasarkan pada taksonomi Bloom (Maulani, dkk., 2020).

Keterampilan kewarganegaraan atau sering disebut sebagai civic skill terbagi atas keterampilan berpartisipasi atau participatory skills dan keterampilan intelektual atau intellectual skills (Al Muctar, 2000). Keterampilan berbartisipasi dapat diwujudkan dengan adanya interaksi serta komunikasi terhadap masalah-masalah politik (Wijaya, 2018). Keterampilan intektual dapat diwujudkan dalam bentuk kegiatan pameran dan membuat tugas project hasil pembelajaran (Wijaya, 2020).

Pembelajaran PKn dapat berbentuk 1) mencari referensi dari berbagai sumber, 2) menelaah dan membaca, 3) diskusi, 4) presentasi, 5) menanggapi, 6) memecahkan kasus/masalah, 7) pengamatan, 8) simulasi, 9) demonstrasi, dan 10) memberikan contoh (Cholisin, 2011) untuk memperkuat karakter dan jati diri bangsa sesuai dengan semangat Bhineka Tunggal Ika dan Pancasila (Brata, Mahatmaharti, Istianingrum, Hasanudin, \& Hadi, 2020).

Bentuk pembelajaran PPKn di kelas XII MIPA 1 SMA Negeri 2 Negara, Kabupaten Jembrana, Bali sudah merujuk dari beberapa poin yang dijelaskan oleh pakar di atas. Namun, hasil belajar siswa pada matapelajaran PPKn khususnya pada materi Perlindungan dan Penegakan Hukum di Indonesia masih di bawah KKM. Hanya ada beberapa siswa yang sudah memiliki ketuntasan belajar. Hal ini dapat dikatakan bahwa ketuntasan belajar secara klasikal kelas XII MIPA 1 belum berhasil atau tuntas. Hal ini dapat dilihat dari hasil tes siswa pada materi ini. Hasil wawancara dengan salah satu siswa menunjukkan bahwa materi ini sangat sulit untuk dipelajari. Selain itu, ada beberapa siswa masih bingung menjawab soal yang diberikan oleh guru karena pilihan jawaban hampir sama semua. Kedua permasalahan pada pembelajaran PPKn harus segera diberikan solusi. Salah satu solusi yang diberikan guru adalah penerapan pembelajaran direct instruction atau pembelajaran langsung.

Direct instruction atau pembelajaran langsung adalah model pembelajaran dengan pola kegiatan bertahap langkah demi langkah sebagai penunjang proses belajar pengetahuan prosedural dan deklaratif (Arends, 2008; Trianto, 2007) yang berkaitan dengan keterampilan dan pengetahuan (Astutik, dkk., 2020).

Langkah-langkah implementasi model pembelajaran direct instruction atau pembelajaran langsung adalah 1) fase penyampaian tujuan (orientasi), 2) fase demonsrasi (presentasi), 3) fase latihan terbimbing, 4) fase mengecek pemahaman siswa dan memberikan feedback (umpan balik), dan 5) fase latihan mandiri (Shoimin, 2014). Bruce, Weil, dan Calhoun (2009) menambahkan bahwa sintaks model pembelajaran langsung terdiri dari lima fase, yaitu, 1) orientasi, presentasi, latihan terbimbing, dan latihan mandiri.

Kelebihan model pembelajaran direct instruction atau pembelajaran langsung adalah 1) dapat menyampaikan materi yang banyak dengan waktu yang singkat, 2) dapat 
menekankan pada materi-materi penting, 3) tidak membuat siswa tertekan/stress, 4) wadah informasi tidak langsung, 5) dapat memberikan tantangan (Sudrajat dalam Anori, Putra, dan Asrizal, 2013).

Hasil penelitian Suprapto (2016) menunjukkan bahwa pembelajaran langsung dapat meningkatkan pemahaman dan aktivitas siswa pada materi hukum, dapat meningkatkan prestasi belajar (Sekar, 2020), dapat meningkatkan hasil belajar siswa (Sudirah, 2020) serta pemberian tugas melalui surel pada pembelajaran langsung berpengaruh terhadap hasil belajar siswa (Ahmad dan Yunus, 2014).

Model pembelajaran langsung memiliki kelemahan. Kelemahan itu antara lain 1) tidak melayani perberdaan peserta didik, 2) menekankan pada komunikasi satu arah, 3) kontrol untuk pemahaman siswa sangat terbatas (Sanjaya, 2007), 4) membutuhkan waktu realtif lama, 5) keberhasilan implementasi metode ini terbatas oleh kemampuan guru (Sulisnayanti, 2009).

Kelemahan pada model pembelajaran langsung di atas juga berdampak saat guru akan merancang model pembelajaran yang akan digunakan mengajar matapelajaran PPKn di kelas XII MIPA 1 SMA Negeri 2 Negara, Kabupaten Jembrana, Bali terutama pada materi Perlindungan dan Penegakan Hukum di Indonesia. Selain itu, kendala lain yang sangat krusial adalah dengan adanya pandemi covid-19. Kedua kondisi ini mengharuskan guru membuat sebuh inovasi pembelajaran yang tetap berdasarkan pada model pembelajaran langsung.

Inovasi yang dirancang oleh guru adalah mengimplementasikan model pembelajaran direct instruction dengan berbantukan LMS google classroom.

LMS google classroom dipilih karena mudah digunakan oleh siswa kelas XII MIPA 1 SMA Negeri 2 Negara yang tempat tinggal mereka di desa maupun di kota. Hal ini didasarkan dari hasil wawancara dengan salah satu siswa, bahwa dia tertarik dan nyaman belajar daring dengan menggunakan aplikasi google classroom saat di rumah.

Google classroom adalah aplikasi berbasis open sources (Faruq, dkk., dalam Hanifah dan Putri, 2020) yang dibuat oleh google sebagai sistem manajemen pembelajaran (Wicaksono, 2020) untuk melakukan komunikasi, berbagi file, dan diskusi (Sewang, 2017) sehingga membantu guru dan siswa dalam pembelajaran (Pradana, 2017).

Google classroom dapat diintegrasikan dengan quizizz (Handayani \& Wulandari, 2021) dan google form (Musdholifah, dkk., 2020) serta terhubung dengan youtube dan situs-situs internet (Setiawan, dkk., 2019) sehingga dampak postif dalam pembelajaran (Afrianti, 2018) dan kebermanfaatan google classroom dapat dimanfaatkan (Basri, dkk., 2020).

Hasil penelitian Hasanudin,

Supriyanto, dan Pristiwati (2020) menjelaskan bahwa LMS google classroom yang dielaborasi dengann model pembelajaran flipped classroom dapat menumbuhkan self-development siswa.

Sintaks model pembelajaran direct instruction berbantukan google classroom pada penelitian ini dapat dilihat pada tabel berikut.

Tabel 1. Sintaks model pembelajaran direct instruction berbantukan google classroom

\begin{tabular}{cll}
\hline Tahapan & Kegiatan & Sintaks model pembelajaran direct instruction berbantukan \\
google classroom
\end{tabular}




\begin{tabular}{ccl}
\hline Tahapan & Kegiatan & Sintaks model pembelajaran direct instruction berbantukan \\
google classroom
\end{tabular}

Dikembangan dari teori Supriyono (2003)

Penelitin ini penting dilakukan mengingat materi Perlindungan dan Penegakan Hukum di Indonesia sangat berguna bagi siswa kelas XII MIPA 1 SMA Negeri 2 Negara sehingga siswa harus benar-benar memiliki hasil belajar yang tinggi dalam mengikuti pembelajaran. Oleh karena itu, untuk mengakomodasi hal tersebut, peneliti ingin menerapkan pembelajaran direct instruction berbantukan google classroom.

\section{METODE PENELITIAN}

Penelitian ini tergolong Penelitian Tindakan Kelas (PTK). PTK dilaksanakan dengan menerapkan berbagai inovasi untuk meningkatkan kualitas dan produktivitas proses pembelajaran (Sanjaya, 2016) yang hasilnya dapat dikenakan langsung oleh masyarakat (Arikunto, 2012). Penelitian ini dilakukan pada semester ganjil tahun akademik 2020/2021 di kelas XII MIPA 1 SMA Negeri 2 Negara, Jembrana, Bali dengan subjek penelitian sebanyak 34 yang terdiri dari 15 siswa laki-laki dan 19 siswa perempuan.

Instrumen pada penelitian ini menggunakan soal tes, pedoman observasi, pedoman wawancara. Soal tes digunakan peneliti untuk mengukur peningkatan hasil belajar siswa tentang materi materi Perlindungan dan Penegakan Hukum di Indonesia, pedoman wawancara digunakan peneliti untuk memvalidasi tes hasil belajar selama mengikuti pembelajaran. Pedoman observasi digunakan peneliti untuk mengamati aktivitas siswa-siswa selama proses pembelajaran.

Data penelitian ini dikumpulkan dengan menggunakan metode tes, observasi, dan wawancara. Metode tes digunakan untuk mengukur peningkatan hasil belajar siswa kelas XII MIPA 1 SMA Negeri 2 Negara dalam menjawab soal yang mencakup 25 Indikator Pencapaian Kompetensi (IPK). Tes yang digunakan pada penelitian ini adalah menggunakan soal pilihan ganda. Tes terlebih dahulu dikonsultasikan oleh validator. Validator yang ditunjuk adalah guru PPKn lain di SMAN 2 Negara. Langkah yang dibuat peneliti dalam mengumpulkan data melalu metode tes yaitu 1) menyusun kisi-kisi, 2) membuat soal, 3) memvalidasi soal, 4) membagikan soal yang sudah tervalidasi, 5) mengujikan soal tes, 5) mengoreksi hasil jawaban, 6) menganalisis. Adapun rubrik penilian prestasi belajar dapat dilihat pada tabel berikut.

Tabel 2. Rubrik penilaian hasil belajar

\begin{tabular}{llll}
\hline No & \multicolumn{1}{c}{ Aspek } & \multicolumn{1}{c}{$\begin{array}{c}\text { Deskripsi } \\
\text { Penilaian }\end{array}$} & Skore \\
\hline 1. & Pengertian perlindungan hukum & a. Benar & 1 \\
& faktor-faktor yang dapat mempengaruhi pelaksanaan penegakan & b. Salah & 0 \\
2. & a. Benar & 1 \\
& hukum & b. Salah & 0
\end{tabular}




\begin{tabular}{|c|c|c|c|}
\hline No & Aspek & $\begin{array}{l}\text { Deskripsi } \\
\text { Penilaian }\end{array}$ & Skore \\
\hline \multirow{2}{*}{3.} & \multirow[b]{2}{*}{ Supremasi hukum } & a. Benar & 1 \\
\hline & & b. Salah & 0 \\
\hline \multirow{2}{*}{4.} & \multirow{2}{*}{ Bentuk perlindungan yang diberikan negara } & a. Benar & 1 \\
\hline & & b. Salah & 0 \\
\hline \multirow{2}{*}{5.} & \multirow{2}{*}{ Syarat perlindungan dan penegakan hukum } & a. Benar & 1 \\
\hline & & b. Salah & 0 \\
\hline \multirow{2}{*}{6.} & \multirow{2}{*}{ Penegak hukum } & a. Benar & 1 \\
\hline & & b. Salah & 0 \\
\hline \multirow{2}{*}{7.} & \multirow{2}{*}{ kewenangan Mahkamah Konstitusi } & a. Benar & 1 \\
\hline & & b. Salah & 0 \\
\hline \multirow{2}{*}{8.} & \multirow{2}{*}{ Orang yang berprofesi memberi jasa hukum } & a. Benar & 1 \\
\hline & & b. Salah & 0 \\
\hline \multirow{2}{*}{9.} & \multirow{2}{*}{ Peradilan } & a. Benar & 1 \\
\hline & & b. Salah & 0 \\
\hline \multirow{2}{*}{10.} & \multirow{2}{*}{ Komisi Pemebrantasan Korupsi } & a. Benar & 1 \\
\hline & & b. Salah & 0 \\
\hline \multirow{2}{*}{11.} & \multirow{2}{*}{ tugas dan wewenang kejaksaan } & a. Benar & 1 \\
\hline & & b. Salah & 0 \\
\hline \multirow[t]{2}{*}{12.} & \multirow[t]{2}{*}{ hak-hak advokat } & a. Benar & 1 \\
\hline & & b. Salah & $\begin{array}{l}0 \\
1\end{array}$ \\
\hline 13. & Kepolisian Republik Indonesia & $\begin{array}{l}\text { b. Salah } \\
\text { b. Sulat }\end{array}$ & 0 \\
\hline \multirow{2}{*}{14.} & \multirow{2}{*}{ Mahkamah Agung } & a. Benar & 1 \\
\hline & & b. Salah & 0 \\
\hline \multirow{2}{*}{15.} & advokat & a. Benar & 1 \\
\hline & advokal & b. Salah & 0 \\
\hline 16 & unava nerlindungan dan nenegakan hukum & a. Benar & 1 \\
\hline 16. & upaya perlındungan dan penegakan nuкum & b. Salah & 0 \\
\hline 17. & Perbuatan melanggar hukum & a. Benar & 1 \\
\hline & 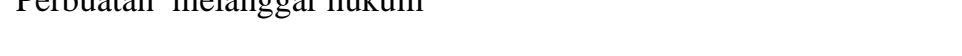 & b. Salah & 0 \\
\hline 18. & Pelanggaran hukum & a. Benar & 1 \\
\hline & & b. Salah & 0 \\
\hline 19. & Sanksi melanggar peraturan hukum perdata & a. Benar & 1 \\
\hline 20 & Pacal 10 Kitah Undano_Indano Hukum Pidana & a. Benar & 1 \\
\hline 20 . & 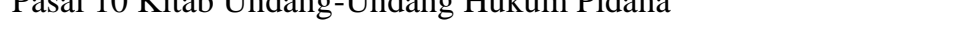 & b. Salah & 0 \\
\hline 21. & Pasal 291 UU No 22 tahun 2009 Tentang Lalu Lintas dan & a. Benar & 1 \\
\hline & Angkutan Jalan & b. Salah & 0 \\
\hline 22 & Sikap positif warga negara terhadap upaya perlindungan dan & a. Benar & 1 \\
\hline & penegakan hukum & b. Salah & 0 \\
\hline 23. & bukti penegakan hukum oleh aparat penegak hukum & a. Benar & 1 \\
\hline 24 & Sikap positif sebagai perwujudan upaya perlindungan dan & a. Benar & 1 \\
\hline 24 & penegakan hukum & b. Salah & 0 \\
\hline 25. & Penegakan hukum & a. Benar & 1 \\
\hline & & b. Salah & 0 \\
\hline
\end{tabular}

Peneliti melakukan wawancara kepada siswa kelas XII MIPA 1, SMAN 2 Negara untuk memvalidasi tes hasil belajar siswa selama mengikuti pembelajaran. Wawancara ini dilakukan oleh peneliti secara tidak terstruktur dengan pertanyaan open ended.
Peneliti melakukan observasi untuk mengukur keberhasilan penerapan model pembelajaran model pembelajaran direct instruction berbantukan google classroom apakah benar-benar dapat meningkatkan hasil belajar siswa. 
Data penelitian ini divalidasi dengan teknik triangulasi. Triangulasi data menurut Denzin dalam Hasanudin, Fitrianingsih, \& Saddhono (2019) memiliki empat tipe, yaitu triangulasi data, peneliti, metode, dan teori. Peneliti menggunakan triangulasi teori dan data. Pada triangulasi teori, peneliti mencocokan hasil penelitian dengan teori yang terdapat pada buku nasional maupun internasional serta dari hasil penelitian terdahulu yang sudah terbit pada jurnal nasional maupun internasional. Pada triangulasi data, peneliti membandingkan data hasil tes dengan data hasil wawancara untuk mengetahui peningkatan hasil belajar, dan data hasil observasi dengan hasil wawancara untuk mengetahui keakuratan hasil prestasi siswa.

Teknik analisis data yang digunakan peneliti adalah teknik deksriptif komparatif. Teknik deskriptif komparatif yaitu membandingkan hasil kondisi awal, setelah siklus 1, dan setelah siklus 2 untuk mengetahui meningkatnya kemampuan siswa (Oktaviani, Kristin, \& Anugraheni, 2018). Data prestasi hasil belajar siswa didasarkan pada kriteria penilaian seperti tabel berikut ini.

Tabel 3. Tabel Kriteria penilaian

\begin{tabular}{cccc}
\hline Rentang & Predikat & $\begin{array}{c}\text { Frekuensi } \\
\text { Absolut }\end{array}$ & $\begin{array}{c}\text { Frekuensi } \\
\text { Relatif (\%) }\end{array}$ \\
\hline $85-100$ & Sangat Baik & & \\
$70-84$ & Baik & & \\
$55-69$ & Cukup & \\
$40-54$ & Kurang & \\
$0-39$ & Sangat Kurang & \\
\hline \multicolumn{5}{c}{ Jumlah } & Adaptasi dari Hamalik (1989)
\end{tabular}

Indikator keberhasilan penelitian ini dapat dilihat dari adanya peningatakan hasil belajar siswa di atas nilai Kriteria Ketuntasan Minimal (KKM), yaitu 70. Nilai ketuntasan klasikal ditentukan apabila ada $75 \%$ dari jumlah siswa yang mendapat nilai sama dengan atau lebih besar dari 70 .

\section{HASIL DAN PEMBAHASAN}

Hasil dan pembahasan ini mencakup hasil belajar siswa pada 1) pratindakan, 2) siklus 1, dan 3) siklus 2 pada model pembelajaran direct instruction berbantukan google classroom. Hal ini akan dijabarkan sebagai berikut.

\section{Hasil belajar siswa pada pratindakan}

Prestasi belajar siswa kelas XII MIPA 1, SMAN 2 Negara pada kegiatan pratindakan belum ada yang mendapat kategori sangat baik. 10 siswa memiliki kategori baik dengan frekuensi relatif 29,41\%, 7 siswa berkategori cukup dengan frekuensi relatif $20,59 \%$, dan 16 siswa berkategori kurang dengan frekuensi relatif 47,06\%, 1 siswa berkategori sangat kurang dengan frekuensi relatif $2,94 \%$. Setelah nilai siswa terkategori, selanjutnya nilai tersebut dapat dimasukkan pada tebel distribusi frekuensi berikut.

Tabel 4. Distribusi frekuensi hasil belajar pada pratindakan

\begin{tabular}{ccc}
\hline Interval & $\begin{array}{c}\text { Frekuensi } \\
\text { Absolut }\end{array}$ & $\begin{array}{c}\text { Frekuensi } \\
\text { Relatif }(\%)\end{array}$ \\
\hline $71-74$ & 10 & 29,41 \\
$66-70$ & 0 & - \\
$61-65$ & 0 & - \\
$56-60$ & 7 & 20,59
\end{tabular}




\begin{tabular}{ccc}
\hline Interval & $\begin{array}{c}\text { Frekuensi } \\
\text { Absolut }\end{array}$ & $\begin{array}{c}\text { Frekuensi } \\
\text { Relatif (\%) }\end{array}$ \\
\hline $51-55$ & 5 & 14,71 \\
$46-50$ & 2 & 5,88 \\
$41-45$ & 6 & 17,65 \\
$36-40$ & 4 & 11,76 \\
\hline Jumlah & $\mathbf{3 4}$ & $\mathbf{1 0 0 , 0 0}$ \\
\hline
\end{tabular}

Berdasarkan pada distribusi frekuensi nilai di atas, dapat dijelaskan bahwa masih banyak siswa kelas XII MIPA 1, SMAN 2 Negara yang mendapat nilai di bawah KKM yang telah ditentukan. Pada kegiatan pratindakan terdapat 24 siswa yang belum tuntas dan hanya 10 siswa yang tuntas. Berdasarkan nilai-nilai tersebut, maka dapat ditentukan bahwa persentase ketuntasan hasil belajar siswa siswa kelas XII MIPA 1, SMAN 2 Negara pada pratindakan sebesar $29,41 \%$ dengan persentase keberhasilan $56,35 \%$.

Mengetahui kondisi pada pratindakan ini, peneliti melakukan telaah dari hasil tes dan observasi. Untuk meningkatkan hasil belajar siswa pada materi Perlindungan dan Penegakan Hukum di Indonesia peneliti membuat rancangan model pembelajaran direct instruction berbantukan google classroom. Hasil belajar siswa setelah dibelajarkan dengan model pembelajaran direct instruction berbantukan google classroom dapat dilihat pada siklus I dan II.

\section{Hasil belajar siswa pada siklus I}

Pada siklus I peneliti mengimplementasikan model pembelajaran direct instruction berbantukan google classroom dengan harapan hasil belajar siswa kelas XII MIPA 1, SMAN 2 Negara dapat meningkat. Berdasarkan hasil tes pada siklus II, terdapat 15 siswa yang sudah tuntas dalam pembelajaran. Ketuntasan ini didasarkan pada nilai KKM mata pelajaran PPKn. Meskipun sudah ada 15 siswa yang sudah tuntas dalam belajar, namun tidak ada satu siswa pun yang memiliki kategori baik pada siklus I, selain itu, ada 15 siswa berkategori baik dengan frekuensi relatif 44,12\%, 8 siswa berkategori cukup dengan frekuensi relatif $23,53 \%$, dan 11 siswa berkategori kurang dengan frekuensi relatif 32,35 , namun, pada siklus I masih ada baiknya karena tidak ada siswa yang berkategori sangat kurang. Nilai 34 siswa tersebut selanjutnya disusun dalam bentuk tabel distribusi frekuensi seperti berikut.

Tabel 5. Distribusi frekuensi hasil belajar pada siklus I

\begin{tabular}{ccc}
\hline Interval & $\begin{array}{c}\text { Frekuensi } \\
\text { Absolut }\end{array}$ & $\begin{array}{c}\text { Frekuensi } \\
\text { Relatif }(\%)\end{array}$ \\
\hline $78-82$ & 6 & 17,65 \\
$73-77$ & 5 & 14,71 \\
$68-72$ & 4 & 11,76 \\
$63-67$ & 1 & 2,94 \\
$58-62$ & 3 & 8,82 \\
$53-57$ & 4 & 11,76 \\
$48-52$ & 11 & 32,35 \\
\hline Jumlah & $\mathbf{3 4}$ & $\mathbf{1 0 0 , 0 0}$ \\
\hline
\end{tabular}


Berdasar pada data distribusi frekuensi hasil belajar pada siklus I. nilai siswa kelas XII MIPA 1, SMAN 2 Negara mengalami peningkatan. Namun peningkatan nilai ini belum dapat dikatakan sebagai bentuk ketuntasan dalam belajar karena prosentase ketuntasan pada siklus I sebesar $44,11 \%$ dengan prosentase keberhasilan $63,65 \%$. Hal ini berarti belum ada $75 \%$ siswa yang mendapat nilai 70 . Berdasarkan data pada siklus I ini, peneliti melakukan evalusi pada proses pembelajaran dengan menerapakan model pembelajaran direct instruction berbantukan google classroom kemudian membuat rancangan pembelajaran pada siklus II. Pada siklus II ini peneliti berharap $75 \%$ siswa kelas
XII MIPA 1, SMAN 2 Negara banyak mendapat nilai di atas 70 .

\section{Hasil belajar siswa pada siklus II}

Pada siklus II peneliti memberikan perlakukan yang sama seperti pada siklus II, mulai dari proses dan tes yang diberikan. Pada siklus II, nilai siswa kelas XII MIPA 1, SMAN 2 Negara mengalami peningkatan. Peningkatan hasil belajar ini dapat dilihat dari tidakadanya siswa yang mendapat predikat sangat kurang atau bahkan kurang pun tidak ada. Pada siklus II terdapat 7 siswa memiliki predikat sangat baik dengan frekuensi relatif 20,59\%, 23 siswa memiliki predikat baik dengan frekuensi relatif $67,65 \%, 4$ siswa memiliki predikat cukup dengan frekeunsi relatif $11,76 \%$. Nilai-nila tersebut dapat dilihat pada tabel distribusi frekuensi berikut.

Tabel 6. Distribusi frekuensi hasil belajar pada siklus II

\begin{tabular}{ccc}
\hline Interval & $\begin{array}{c}\text { Frekuensi } \\
\text { Absolut }\end{array}$ & $\begin{array}{c}\text { Frekuensi } \\
\text { Relatif (\%) }\end{array}$ \\
\hline $85-89$ & 7 & 20,59 \\
$80-84$ & 11 & 32,35 \\
$75-79$ & 5 & 14,71 \\
$70-74$ & 7 & 20,59 \\
$65-69$ & 2 & 5,88 \\
$60-64$ & 2 & 5,88 \\
\hline Jumlah & $\mathbf{3 4}$ & $\mathbf{1 0 0 , 0 0}$ \\
\hline
\end{tabular}

Berdasar pada data distribusi frekuensi hasil belajar pada siklus II. nilai siswa kelas XII MIPA 1, SMAN 2 Negara mengalami peningkatan. Pada siklus II terdapat 30 siswa yang sudah tuntas belajar dan 4 siswa belum tuntas belajar. Prosentase ketuntasan siklus II sebesar $88,23 \%$ dengan prosentase keberhasilan sebesar $77,76 \%$. Hal ini artinya bahwa harapan peneliti pada siklus II terjawab karena sudah ada $75 \%$ siswa mendapat nilai
70. Secara teori bahwa terdapat peningkatan dari mulai siklus I dan II setelah siswa dibelajarkan dengan menerapakan model pembelajaran direct instruction berbantukan google classroom.

Bentuk peningkatan prestasi belajar siswa kelas X MIPA 3, SMAN 1 Negara pada setiap kegiatan dapat digambarkan pada diagram berikut. 


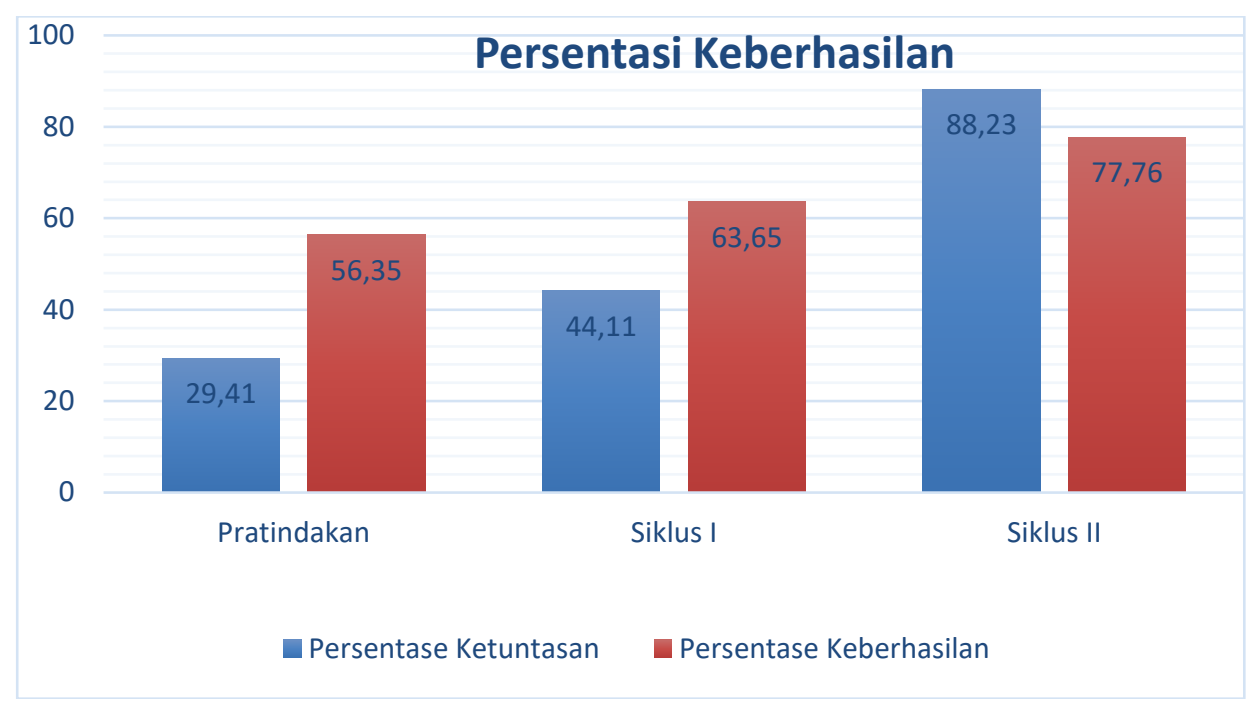

Gambar 1. Diagram persentase ketuntasan dan persentasi keberhasilan

\begin{abstract}
Diagram di atas menggambarkan bahwa model pembelajaran direct instruction berbantukan google classroom dapat meningkatkan prestasi siswa kelas XII MIPA 1, SMAN 2 Negara pada mata pelajaran PPKn khususnya materi Perlindungan dan Penegakan Hukum di Indonesia.
\end{abstract}

Hasil penelitian ini sejalan dengan hasil penelitian yang dilakukan oleh Mabrur, Setiawan dan Mubarok (2021) menyebutkan bahwa model pembelajaran direct instruction memberikan pengaruh terhadap hasil belajar siswa, dapat meningkatkan kemampuan siswa (Sulastri, 2021), dan dapat meningkatkan hasil belajar siswa.

Selain itu penggunaan google classroom pada penelitian ini juga memberikan dampak yang positif dalam membantu meningkatkan hasil belajar siswa, hal ini senada dengan hasil penelitian Rahma dan Arista (2021) menjelaskan bahwa google classroom sebagai media digital yang dapat membantu pengajar untuk mengelola kelas secara daring, dapat peningkatan kemampuan siswa dalam memecahkan masalah (Nugraheni, 2021), serta memberikan kemudahan dalam proses pembelajaran yang masih tetap mengacu pada RPP (Badruzaman, 2021). Google classroom juga dapat diintegrasikan dengan quizizz (Handayani dan Wulandari, 2021)

\section{SIMPULAN}

Hasil belajar siswa kelas XII MIPA 1, SMAN 2 Negara selama mengikuti pembelajaran dengan model pembelajaran direct instruction berbantukan google classroom pada materi Perlindungan dan Penegakan Hukum di Indonesia mulai dari kegiatan pratindakan sampai siklus II mengalami peningkatan. Peningkatan hasil belajar tersebut dapat dilihat dari persentase ketuntasan klasikal dan persentase keberhasilan mulai dari kegiatan pratindakan, siklus I, dan siklus II. Pada kegiatan pratindakan, persentase ketuntasan klasikal sebesar 29,41\% dan persentase keberhasilan sebesar 56,35\%. Pada kegiatan siklus I, persentase ketuntasan klasikal sebesar $44,11 \%$ dan persentase keberhasilan sebesar $63,65 \%$. Pada kegiatan siklus II, persentase ketuntasan klasikal sebesar $88,23 \%$ dan persentase keberhasilan sebesar $77,75 \%$. Hal ini dapat disimpulkan bahwa hasil belajar siswa pada setiap siklus mengalami peningkatan dan sebanyak $75 \%$ siswa sudah mendapat nilai di atas 70 (KKM mata pelarajan PPKn). 


\section{DAFTAR RUJUKAN}

Afrianti, W. E. (2018). Penerapan google classroom dalam pembelajaran akuntansi (Studi Pada Program Studi Akuntansi Universitas Islam Indonesia) (skripsi, Universitas Islam Indonesia Yogyakarta, Indonesia).

Ahmad, L. F., \& Yunus, M. (2014). Pengaruh E-Mail pada Pemberian Tugas dengan Menggunakan Pembelajaran Langsung terhadap Hasil Belajar Siswa Kelas XI IPA SMA Negeri 1 Bajeng (Studi pada Sub. Materi Pokok Hidrolisis Garam). Chemica: Jurnal Ilmiah Kimia dan Pendidikan Kimia, 15(2), 1-15. Retrieved from https://ojs.unm.ac.id/chemica/article /view/4587.

Al Muchtar, S. (2000). Pengembangan Kemampuan Berpikir dan Nilai Dalam Pendidikan IPS. Bandung, Indonesia: Gelar Pustaka Mandiri.

Anori, S., Putra, A., Asrizal (2013). Pengaruh penggunaan buku ajar elektronik dalam model pembelajaran langsung terhadap hasil belajar siswa kelas X SMAN 1 Lubuk Alung. Pillar of Physics Education, 1(1), 104-111. Retrieved from

http://ejournal.unp.ac.id/students/ind ex.php/pfis/article/view/498/287.

Arends, R. (2008). Learning to Teach. New York: The McGrawHill companies.

Arikunto, S., dkk. (2012). Penelitian tindakan kelas. Jakarta, Indonesia: Bumi Aksara.

Astutik, E. Y., dkk. (2020). Penerapan model pembelajaran langsung (direct instruction) pada kompetensi dasar perawatan kulit wajah secara manual di SMK Negeri 3 Kediri. Jurnal Tata Rias, 9(4), 82-90. Retrieved from https://jurnalmahasiswa.unesa.ac.id/i ndex.php/jurnal-tata-

rias/article/view/35837/31877.

Badruzaman, M. (2021). Penerapan pembelajaran jarak jauh menggunakan google classroom untuk meningkatkan hasil belajar pada masa pandemi. Jurnal Al-Amar (Ekonomi Syariah, Perbankan Syariah, Agama Islam, Manajemen dan Pendidikan), 2(1), 22-31. Retrieved from http://www.journal.steialamar.com/oj s1/index.php/alamar/article/view/68.

Basri, dkk. (2020). Pelatihan pemanfaatan sistem pembelajaran daring bagi guru-guru SMA di Kecamatan Palas, Kabupaten Lampung Selatan. J-Abdipamas (Jurnal Pengabdian Kepada Masyarakat), 4(2), 53-58. Doi http://dx.doi.org/10.30734/jabdipamas.v4i2.1193.

Birzea, C. (2000). Education for democratic citizenship: a lifelong learning perspective. Strasbourg: Council of Europe.

Brata, D. N. P., Mahatmaharti, R. R. A. K., Istianingrum, R., Hasanudin, C., \& Hadi, S. (2020). Developing pancasila and civic education (PPKN) based on local wisdom. Humanities \& Social Sciences Reviews, 8(1), 768-773. Doi https://doi.org/10.18510/hssr.2020.81 92.

Bruce, J., Weil, M. dan Calhoun E. (2009). Model of Teaching (Eighth Edition). Boston: Pearson.

Cholisin. (2011). Pengembangan Karakter Dalam Materi Pembelajaran Pkn. Yogyakarta, Indonesia: Universitas Negeri Yogyakarta.

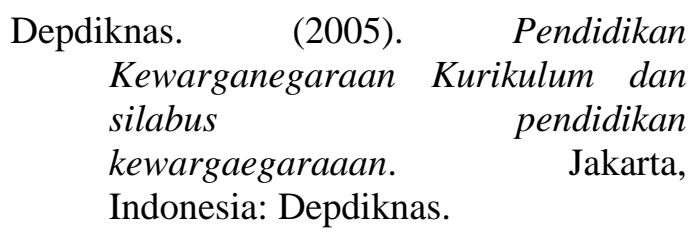


Dianti, P. (2014). Integrasi Pendidikan Karakter dalam Pembelajaran Pendidikan Kewarganegaraan untuk Mengembangkan Karakter Siswa. JPIS, Jurnal Pendidikan Ilmu Sosial, 2391), 58-68. Doi https://doi.org/10.17509/jpis.v23i1.2 $\underline{062}$.

Hamalik, O. (1989). Teknik pengukur dan evaluasi pendidikan. Bandung, Indonesia: Mandar Maju.

Handayani, R. Wulandari, D. (2021). Modern assessment dalam menyongsong pembelajaran abad 21 dan hambatan di negara berkembang. JPE (Jurnal Pendidikan Edutama), 8(1), 13-24. Doi http://dx.doi.org/10.30734/jpe.v8i1. $\underline{1363}$.

Handayani, R., dan Wulandari, D. (2021). Modern assessment dalam menyongsong pembelajaran abad 21 dan hambatan di negara berkembang. JPE (Jurnal Pendidikan Edutama), 8(1), 13-24. Doi http://dx.doi.org/10.30734/jpe.v8i1.1 363.

Hanifah, W., \& Putri, K. Y. S. (2020). Efektivitas Komunikasi Google Classroom Sebagai Media Pembelajaran Jarak Jauh Pada Mahasiswa Ilmu Komunikai Universitas Negeri Jakarta Angkatan 2018. MEDIALOG: Jurnal Ilmu Komunikasi, 3(2), 24-35. Doi https://doi.org/10.35326/medialog.v3 i2.639.

Hasanudin, C., Fitrianingsih, A., \& Saddhono, K. (2019). How is the student's negotiation text in collaborative learning of flipped classroom and a CyberLink power director media apps. Ingénierie des Systèmes d'Information, 24(6), 559567.

https://doi.org/10.18280/isi.240601.
Hasanudin, C., Supriyanto, R. M. T., Pristiwati, R. (2020). Elaborasi model pembelajaran flipped classroom dan google classroom sebagai bentuk self-development siswa mengikuti pembelajaran bahasa indonesia di era Adaptasi Kebiasaan Baru (AKB). Intelegensia: Jurnal Pendidikan Islam, 8(2), 85-97. Retrieved from https://ejournal.unisnu.ac.id/JI/articl e/view/1414.

Kunandar, D. (2013). Penilaian Autentik (Penilaian Hasil Belajar Peserta Didik Berdasarkan Kurikulum 2013) Suatu Pendekatan Praktis (Edisi Revisi). Jakarta: PT Rajagrafindo Persada.

Lubis, Y. \& Sodeli, M. (2018). Pendidikan Pancasila dan Kewarganegaraan. Edisi revisi 2018. Jakarta, Indonesia: Kementerian Pendidikan dan Kebudayaan.

Mabrur, M., Setiawan, A., \& Mubarok, M. Z. (2021). Pengaruh Model Pembelajaran Direct Instruction Terhadap Hasil Belajar Teknik Dasar Guling Depan Senam Lantai. Physical Activity Journal (PAJU), 2(2), 193-204. Retrieved from

http://jos.unsoed.ac.id/index.php/paju larticle/view/4014/2153.

Masyithah, R. (2021). Penerapan model pembelajaran langsung (direct instruction) untuk meningkatkan hasil belajar siswa pada materi kemagnetan dan pemanfaatannya dalam produk teknologi di MTs. N 3 Aceh Utara tahun ajaran 2018/2019. AL-ILMU, 6(1), 165-179. Retrieved from http://jurnal.kopertais5aceh.or.id/inde x.php/AIJKIS/article/view/173/124.

Maulani, A., dkk. (2020). Korelasi Antara Tingkat Minat Baca dengan Kompetensi Pengetahuan Pendidikan Kewarganegaraan. Jurnal Penelitian dan Pengembangan Pendidikan, 
$4(2), \quad 215-\quad 223 . \quad$ Doi http://dx.doi.org/10.23887/jppp.v4i2. 27347.

Musdholifah, dkk. (2020). Pengembangan media pembelajaran kelas online untuk guru SMA di Kabupaten Magetan. J-Abdipamas (Jurnal Pengabdian Kepada Masyarakat), 4(2), 49-56. Doi http://dx.doi.org/10.30734/jabdipamas.v4i1.673.

Nugraheni, D. (2021). Penerapan Media Pembelajaran Google Classroom Materi Vektor Untuk Meningkatkan Kemampuan Pemecahan Masalah Mahasiswa. WaPFi (Wahana Pendidikan Fisika),6(1), 70-75. Retrieved from https://ejournal.upi.edu/index.php/W PF/article/view/32452/13988.

Oktaviani, W., Kristin, F., \& Anugraheni, I. (2018). Penerapan model pembelajaran discovery learning untuk meningkatkan kemampuan berpikir kritis dan hasil belajar matematika siswa kelas 5 SD. Jurnal Basicedu, 2(2), 5-10. Retrieved from https://media.neliti.com/media/public ations/278118-penerapan-modelpembelajaran-discovery-189110763.pdf.

Permendikbud nomor 49 tahun 2014 pasal 6 ayat 1 Tentang Standar Nasional Pendidikan Tinggi.

Pradana, D. B. P. (2017). Pengaruh penerapan tools google classroom pada model pembelajaran project based learning terhadap hasil belajar siswa. IT-Edu: Jurnal Information Technology and Education, 2(1). Refreived from https://jurnal.unesa.ac.id/index.php/i t-edu/article/view/20527.

Rahma, A. A., \& Arista, H. (2021). Analisis penerapan google classroom untuk meningkatkan mutu pembelajaran online di masa pandemi covid19. Pedagogy: Jurnal Ilmiah Ilmu
Pendidikan, 8(1), 88-95. Doi https://doi.org/10.51747/jp.v8i1.730.

Rattu, J. A. (2017). Penilaian Kompetensi Sikap pada Mahasiswa Jurusan PPKn Fis Unima. Jurnal Civis Education, 1(1), 9-14. Doi https://doi.org/10.36412/ce.v1i1.490.

Rismayani, N. L., dkk. (2013). Penerapan Model Pembelajaran Discovery Learning untuk Meningkatkan Hasil Belajar PKn Siswa. Jurnal Pendidikan Kewarganegaraan Undiksha, 1(2), 1-11. Retrieved from https://ejournal.undiksha.ac.id/index. php/JJPP/article/view/405.

Sanjaya, D. H. W. (2016). Penelitian tindakan kelas. Jakarta, Indonesia: Prenada Media.

Sanjaya, W. (2007). Strategi Pembelajaran Berorientasi Sumber Proses Pendidikan. Jakarta, Indonesia: Kencana.

Sekar, N. N. (2020). Penggunaan Model Pembelajaran Direct Instruction Sebagai Upaya Meningkatkan Prestasi Belajar IPS. Jurnal Ilmiah Pendidikan Profesi Guru, 3(2), 347353.

Doi http://dx.doi.org/10.23887/jippg.v3i 2.29067.

Setiawan, I., dkk. (2019). Bimbingan klasikal penguasaan konten dengan google classroom berbasis pemaknaan cerita rakyat untuk menanamkan nilai-nilai karakter siswa SMP. dalam SEMBIKA: Seminar Nasional Bimbingan dan Konseling. Retrieved from https://conference.umk.ac.id/index.ph p/sembika/article/download/69/81.

Sewang, A. (2017). Keberterimaan Google Classroom sebagai alternatif Peningkatan Mutu di IAI DDI Polewali Mandar. JPPI (Jurnal Pendidikan Islam Pendekatan Interdisipliner), 1(1), 35-46. Retrieved 
https://jppi.ddipolman.ac.id/index.ph p/jppi/article/view/34.

Shoimin, A. (2014). Model Pembelajaran Inovatif dalam Kurikulum 2013. Yogyakarta, Indonesia: Arruzz media.

Sudirah, S. (2020). Penerapan Metode Instruksi Langsung (Direct Instruction) dalam Sistem Pembelajaran Untuk Meningkatkan Hasil Belajar Siswa Pada Mata Pelajaran Matematika Kelas 3 SD. ISEJ: Indonesian Science Education Journal, 1(2), 97-108. Diambil dari https://siducat.org/index.php/isej/arti cle/view/49.

Sulastri, A. (2021). Penerapan model pembelajaran langsung (direct instruction) dalam meningkatkan kemampuan menginterpretasi peta. Jurnal Ilmiah Pro Guru, 3(2), 157-165. Retrieved from http://journal2.um.ac.id/index.php/jip g/article/view/19981/7538.

Sulisnayanti, Y. (2009). Upaya peningkatkan kualitas pembelajaran akuntansi di kelas $\mathrm{x}$ ak 2 smk negeri 3 surakarta melalui penerapan metode direct instruction tahun diklat 2008/2009 (penelitian tindakan kelas) (Skripsi, Universitas Sebelas Maret, Indonesia). Refrieved from https://digilib.uns.ac.id/dokumen/det ail/8733Upaya-peningkatkankualitas-pembelajaran-akuntansi-dikelas-X-ak-2-SMK-Negeri-3Surakarta-melalui-penerapanmetode-direct-instruction-Tahundiklat-20082009-penelitiantindakan-kelas.

Suprapto, H. (2016). Meningkatkan pemahaman dan aktifitas siswa terhadap materi hukum melalui pengimplementasian model pembelajaran langsung pada pengadilan negeri ponorogo. JPK (Jurnal Pancasila dan
Kewarganegaraan), 1(1), 60-70.

doi:

http://dx.doi.org/10.24269/v1.n1.20

16.60-70.

Supriyono. (2003). Strategi Pembelajaran Fisika. Malang, Indonesia: Universitas Negeri Malang.

Tolib dan Nuryadi. (2017). Pendidikan Pancasila dan Kewarganegaraan: buku guru) (Rev. Ed). Jakarta, Indonesia: Pusat Kurikulum dan Perbukuan, Balitbang, Kemendikbud.

Trianto. (2007). Model-Model Pembelajaran Inovatif Berorientasi Konstruktivistik. Jakarta, Indonesia: Prestasi Pustaka Publisher.

UU RI nomor 20 tahun 2003 pasal 37 ayat 1 tentang Sistem pendidikan Nasional.

Wicaksono, M. D. (2020). Pemanfaatan Google Classroom dalam Strategi Pembelajaran Kooperatif pada Mata Pelajaran Ips Kelas Viii. Inspirasi (Jurnal Ilmu-Ilmu Sosial), 17(1). Refrieved from http://www.jurnal.stkippgritulungagu ng.ac.id/index.php/inspirasi/article/vi ew/1568.

Wijaya, A. K. (2018). Pengaruh Model Bermain Peran Berbantuan Multimedia Terhadap Keterampilan Kewarganegaraan Peserta Didik (Tesis, Universitas Pendidikan Indonesia, Indonesia). Retrieved from http://repository.upi.edu/37826/1/T_ PKn_1604859_Title.pdf.

Wijaya, A. K. (2020). Integrasi Model Pembelajaran Role Playing dengan Multimedia Dalam Meningkatkan Keterampilan .Partisipasi Sosial Siswa. Edueksos: Jurnal Pendidikan Sosial \& Ekonomi, 9(1), 98-113. Doi http://dx.doi.org/10.24235/edueksos. v9i1.6420. 
14 JURNAL PENDIDIKAN EDUTAMA, Vol.8, No.2 Juli 2021

Winataputra, U. \& Budiansyah, D. (2012).

Pendidikan kewarganegaraan

dalam perspektif internasional.

Bandung, Indonesia: Widya Aksara

Press. 